\title{
In vitro Evaluation of Syzygium aromaticum L. Ethanol Extract as Biocontrol Agent against Postharvest Tomato and Potato Diseases
}

\author{
W.B. Suleiman(1), M.M. El Bous ${ }^{(2) \#}$, M. EI Said(2), H. El Baz ${ }^{(2)}$ \\ (1)Botany and Microbiology Department, Faculty of Science, Al Azhar University, \\ Cairo, Egypt; ${ }^{(2)}$ Botany Department, Faculty of Science Port-Said University, Port- \\ Said, Egypt.
}

\begin{abstract}
$\mathbf{E}$ THANOLIC extract of dried flower bud of Syzygium aromaticum L. (clove) was investigated to evaluate its antifungal activity against local fungal isolates causing postharvest infections form potato and tomato. Four fungal isolates; Geotrichum candidum, Alternaria alternata, Fusarium oxysporum and Mucor hiemalis were identified. All fungal isolates were found to be inhibited by the extract; whereas the smallest inhibition zone) of $S$. aromaticum extract was $2.5 \%$ for M. hiemalis, A. alternata, G. candidum and $12.5 \%$ for $F$. oxysporum. Quantitative assessment of phytochemical compounds in clove plant revealed the presence of phenolic acids $(20.80 \%)$; flavonoids $(26.81 \%)$; tannins $(4.90 \%)$, saponins $(2.60 \%)$, alkaloids $(1.60 \%)$, total protein $(17.83 \%)$, total carbohydrate $(2.23 \%)$ and total oil $(0.90 \%)$. Biochemical profile was revealed by GC/MS which detect 18 different chemical compounds. The major compounds were eugenol $(17.27 \%)$, trans-caryophyllene $(0.50 \%)$, humulene $(3.33 \%)$, anthracenedione $(3.35 \%)$, cedran-diol $(0.61 \%)$, citroflex A $(5.45 \%)$ and lucenin 2 $(8.25 \%)$. TLC technique and different solvent systems were employed to select the proper one based on its capacity to isolate the maximum number of fluorescent spots in crude extract. Chloroform-acetone-butanol (CAB) 85:15:20 could efficiently separate three bands (A, B and $\mathrm{C})$. Each detected band was individually screened for its antifungal activity against the isolated fungi. Only band $\mathrm{C}$ showed a significant antifungal activity. Mass spectroscopy (MS) was used to investigate characteristics, purity as well as expectation of both chemical formula and molecular weight of the isolated compounds; which finally proved that glucoside $\beta$-sitosterol was the main compound represented in fraction -C.
\end{abstract}

Keywords: Syzygium aromaticum, Antifungal, Post-harvest, Secondary metabolites, TLC, GC/MS.

\section{Introduction}

Fungi are common pathogens and the main cause of crop diseases. They affect most of fruits and vegetables during storage and transport. Mold growth depends on many factors such as $\mathrm{pH}$, water activity, temperature, atmosphere and time. Fruit infection by fungi may appear during the growth, or due to the improper harvesting, handling, packaging, transportation, post-harvest stocks and marketing conditions, or after purchase by the consumer (Abdullah et al., 2016). Much of these losses are due to the attack of several fungal pathogens because, after harvest, fruits have lost most of the intrinsic resistance that protect them while they are attached to the plant. In addition, most of the post-harvest pathogens require a wound for their penetration (Droby et al., 1992). Generally, phytopathogenic fungi are controlled by synthetic fungicides; however, the use of these is increasingly restricted because fungicides represent a danger to the health of humans, animals, and the environment (Harris et al., 2001). In recent years, effort to reduce the use of chemical pesticides in agriculture has increased. Concerns have been raised about their environmental impact and the potential health risk related to the use of these compounds. Most of the synthetic pesticides are non-biodegradable and thus have the potential to disturb the ecological balance. Development of pesticide resistance in pests is also a major issue in today's agriculture which subsequently leads to an application of greater dose of the pesticide to counteract the resistance. This in turn causes a worsening of the ambient pollution problem. Because of growing

"Corresponding author email: elbousmona@gmail.com

DOI: 10.21608/ejbo.2018.3838.1180

Edited by: Prof. Dr. Salama A. Ouf, Faculty of Science, Cairo University, Cairo, Egypt.

(C)2019 National Information and Documentation Center (NIDOC) 
concerns about health and environmental safety, the use of toxic, carcinogenic and environmentally damaging chemicals is currently being discouraged. Therefore, there is a need to develop alternative agents for the control of pathogenic fungal diseases in plants (Bhuyan \& Das, 2012).

Clove (Syzygium aromaticum L.) is an aromatic dried flower bud of a tree that grows in hot tropical climates, it used as spicy allover the world because the aroma of the clove is pleasant (Bhowmik et al., 2012). Moreover, it has many useful and medical purposes. It is used to control nausea and vomiting, cough, diarrhea, dyspepsia, flatulence, stomach distension and gastro intestinal spasm, relieve pain (Elujoba et al., 2006; Sulieman et al., 2007 and Tanko et al., 2008). In addition, the $S$. aromaticum are highly antimutagenic (Miyazawa \& Hisama, 2003) antiinflammatory (Kim et al., 1998), antioxidant (Chaieb et al., 2007), antithrombotic (Srivastava \& Malhotra, 1991). Recently, antibacterial and antifungal activities of $S$. aromaticum was reported (Kumar et al., 2014 and Hamini-Kada et al., 2014).

The objective of the present research was to evaluate the antifungal activity of ethanolic extract of $S$. aromaticum dried flower buds against some fungi isolated from infected post-harvested potato tubers and tomato fruits collected from the Egyptian markets in addition to preliminary identification of the most dominant secondary metabolites in the crude extract.

\section{Materials and Methods}

\section{Collection of specimens}

Infected potato tubers and tomato fruits showing symptoms of rotting were purchased from local markets at Damietta Governorate and then transferred under aseptic conditions to isolate infectious fungi.

\section{Isolation of fungi}

Infected pieces were cut into $1 \times 1 \mathrm{~cm}^{2}$ segments and then dipped in $70 \%$ ethanol momentary and soaked in solution of $5 \%$ sodium hypochlorite for 1-3min. The sterilized pieces then washed once with sterilize distilled water, then transfer to petri dishes containing Czapek's yeast extract agar medium CYA as described by Gams et al. (1998) which was supplemented with chloramphenicol as an antibacterial agent $\left(0.5 \mathrm{gL}^{-1}\right)$. Two to three pieces were distributed onto surface of the medium. All petri-dishes were then incubated at $25-28^{\circ} \mathrm{C}$ then checked regularly every day, up to 6 days. A portion of growing mycelia was transferred onto a new sterile petri-dishes containing CYA medium for further purification purposes. All purified fungal isolates were re inoculated into new healthy individuals of potato tubers and tomato fruits to investigate the symptoms of rotting and subsequently, performing the pathogenicity test that ensure the ability of the investigated fungi for infection. Finally, all fungal isolates were identified according to their macroscopic and microscopic characteristics (Domsch et al., 1980).

\section{Collection and preparation of plant material}

Dried flower buds of $S$. aromaticum were purchased from local market in Damietta, Egypt. Then they were washed by tap water 3 times followed by sterilized distilled water. They were pounded to powder and then subsequently sieved to remove coarse particles.

Plant material was dissolved in $95 \%$ ethanol $(1: 10 \mathrm{w} / \mathrm{v})$; each $1 \mathrm{~g}$ sample had been dissolved in $10 \mathrm{ml}$ of solvent and extracted on shaker at $150 \mathrm{rpm}$ for $24 \mathrm{~h}$ at room temperature. Mixtures were then filtered through sterile layer of gauze to remove any solid plant materials and then through Whatman No. 1 filter paper. The filtrate was concentrated via evaporation process which was carried out by using rotary evaporator at $35-40^{\circ} \mathrm{C}$.

\section{Evaluation of antifungal activity of S. aromaticum ethanolic extract}

Antifungal activity test

Antifungal activity was determined by well diffusion method which was described by Rojas et al. (2006). Petri dish containing $20 \mathrm{ml}$ of potato dextrose agar (PDA) media according to Beever and Bollard (1970) was inoculated with $250 \mu \mathrm{L}$ spore suspension $\left(1 \times 10^{5} \mathrm{cfu} / \mathrm{ml}\right)$ of seven days-old fungal culture. Six mm wells were made using a sterile cork borer; in each well, $50 \mu \mathrm{L}$ from plant crude extract, antibiotic (ciclopirox-olamine) (positive control) and ethanol (blank) were applied using sterilized dropping micropipettes and then incubated at $27 \mathrm{C}$ ) for 6 days.

Different concentrations $(50 \%, 25 \%, 12.5 \%$, $5 \%, 2.5 \%$ and $1 \%$ ) of clove ethanolic extract were prepared in $95 \%$ ethanol. Well diffusion method described by Al-Kuraishi et al. (2013) was followed to detect inhibitory activity of $S$. 
aromaticum. A Petri dish containing $20 \mathrm{ml}$ of PDA media seeded with $250 \mu \mathrm{L}$ spore suspension $\left(1 \times 10^{5} \mathrm{cfu} / \mathrm{ml}\right)$ of seven days-old fungal cultures was prepared .Wells were made by using sterilized cork borer $(6 \mathrm{~mm})$. In each well $50 \mu \mathrm{L}$ volume of each dilution was applied (triplicate). The plates were incubated at $27^{\circ} \mathrm{C}$ for 6 days, after incubation period, the diameter of inhibition zones around wells were recorded in millimeters. Tests were performed in triplicate.

\section{Preliminary phytochemical screening of $S$. aromaticum}

The ethanolic plant extract was subjected to preliminary qualitative tests for testing the presence of alkaloids, saponins, tannins, steroids and flavonoids according to Harborne (1998).

\section{Quantitative phytochemical screening of $S$. aromaticum.}

Estimation of total flavonoid content

Flavonoid content of extract was determined by colorimetric method described by Chang et al. (2002). The plant extract was separately mixed with $1.5 \mathrm{ml}$ of methanol, $0.1 \mathrm{ml}$ of $10 \%$ aluminum chloride, $0.1 \mathrm{ml}$ of $1 \mathrm{M}$ potassium acetate, and $2.8 \mathrm{ml}$ of distilled water, and left at room temperature for $30 \mathrm{~min}$. The absorbance of the reaction mixture was measured at $415 \mathrm{~nm}$ using spectrophotometer. The samples were prepared in triplicate for each analysis and the mean value of absorbance was obtained. The same procedure was repeated for the standard solution of rutin and the calibration line was construed. Based on the measured absorbance, the concentration of flavonoids was read $(\mathrm{mg} / \mathrm{ml})$ on the calibration line; then, the content of flavonoids in extracts was expressed in terms of rutin equivalent (mg of rutin/ gm of extract).

\section{Estimation of total tannins}

The total tannin content in the plant extract was determined by Folin-Deins reagent method adopted by Polshettiwar et al. (2007). The absorbance was measured at $755 \mathrm{~nm}$.

\section{Estimation of total saponins}

Twenty grams of plant powder was dispersed in $200 \mathrm{ml}$ of $20 \%$ ethanol. The suspension was heated over a water bath for $4 \mathrm{~h}$ with stirring at about $55^{\circ} \mathrm{C}$. The mixture was filtered and the residue was re-extracted with another $200 \mathrm{ml}$ of $20 \%$ ethanol. The combined extracts were reduced to $40 \mathrm{ml}$ over water bath at about $90^{\circ} \mathrm{C}$. Twenty $\mathrm{ml}$ of diethyl ether was added to the concentrate and shaken vigorous. The aqueous layer was recovered while the ether layer was discarded. The purification process was repeated and $60 \mathrm{ml}$ of n-butanol was added. The combined n-butanol extract were washed twice with $10 \mathrm{ml}$ of $5 \%$ aqueous sodium chloride. The remaining solution was evaporated. Then, the samples were dried in the oven to a constant weight. The saponins content was calculated in percentage according to Okwu \& Ukanwa (2007) determination.

\section{Estimation of total alkaloids (gravimetric method) \\ Ten grams of the plant powders was extracted with $90 \%$ ethanol till exhaustion tested with Mayer's reagent using the standard procedure described by Woo \& Püls (1977).}

\section{Estimation of total phenolic content}

Determination of total phenolics in plant extract was determined by using modified FolinCiocalteu method (Maurya \& Singh, 2010). Gallic acid solution (sigma chemical) was used as a standard and prepared in various concentration $2-10 \mu \mathrm{g} / \mathrm{ml}$ to be a standard curve. Concentration of $1 \mathrm{mg} / \mathrm{ml}$ of plant extract was also prepared and $0.5 \mathrm{ml}$ of each sample were introduced into test and mixed with $2.5 \mathrm{ml}$ of a 10 fold dilute Folin- Ciocalteu reagent and $2 \mathrm{ml}$ of $7.5 \%$ sodium carbonate. The tubes were covered with parafilm and allowed to stand for $30 \mathrm{~min}$ at room temperature before the absorbance was read at $760 \mathrm{~nm}$ spectrophotometrically. All determination was performed in triplicate. Determination of total phenol content in the extracts were calculated using the linear regression equation of the calibration curve and expressed as gallic acid equivalent per gram of extract.

\section{Carbohydrates content}

Total, soluble and insoluble carbohydrates were estimated by using the method described by Chaplin \& Kennedy (1994).

Total carbohydrates were extracted by dissolving $1 \mathrm{~g}$ of powder in $2-5 \mathrm{ml}$ of $2 \mathrm{M} \mathrm{HCl}$ in a sealed tube. The sealed tube was heated at $100^{\circ} \mathrm{C}$ for a period of $2-5 \mathrm{~h}$. The extracted sugars were estimated using the general phenol- sulfuric acid assay. The absorbency was measured at $490 \mathrm{~nm}$ after $30 \mathrm{~min}$.

For soluble carbohydrates half gram plant 
powders were extracted with ethanol/water $(80 \%$ $\mathrm{v} / \mathrm{v}$ ) by reflux for $2 \mathrm{~h}$. The alcohol was removed from the alcoholic extract by evaporation under reduced pressure. The aqueous extract was clarified using Carrez reagent, and then its volume was completed to $100 \mathrm{ml}$ with dist. water.

Then calculate insoluble carbohydrates $=$ Total carbohydrates - soluble carbohydrates.

\section{Total nitrogen and protein content}

The total nitrogen and protein content of S. aromaticum was determined using Kjeldahl method (James, 1995).

\section{Steam distillation of volatile oils}

Fifty grams of fresh plant were subjected to steam distillation to extract volatile oils (Balbaa et al., 1981).

\section{Chromatographic characterization of the crude extract of clove \\ Gas chromatography/mass spectrophotometer GC/MS}

The sample was injected by injector $\left(250^{\circ} \mathrm{C}\right)$ into GC/MS equipment (Thermo Scientific TRACE 1310 Gas Chromatograph) which was attached with ISQ LT single quadrupole mass spectrometer (Thermo fisher scientific). The run was done by some help of helium gas with a flow rate of $1.5 \mathrm{Psi} / \mathrm{min}$. Analysis was done by GC/MS provided with a column (DB5-MS, 30m: $0.25 \mathrm{~mm}$ ID (J\&W Scientific), with EI ionization model and ionization voltage of $70 \mathrm{e}$. v. The temperature program was; $50^{\circ} \mathrm{C}(1 \mathrm{~min}), 150^{\circ} \mathrm{C}$ $(1 \mathrm{~min})$ at $7^{\circ} \mathrm{C} / \mathrm{min}, 250^{\circ} \mathrm{C}(5 \mathrm{~min})$ at $5^{\circ} \mathrm{C} / \mathrm{min}$, $290^{\circ} \mathrm{C}(2 \mathrm{~min})$ at $10^{\circ} \mathrm{C} / \mathrm{min}$. The chromatogram was presented by Xcalibur software which was connected with built-in library (WILEY \& NIST MASS SPECTRAL DATA), referring to detector involved with a temperature of $300^{\circ} \mathrm{C}$.

\section{Thin layer chromatography (TLC)}

A sample of ethanolic crude extract was spotted on silica gel plate (60 SF 254e. Merch $20 \times 20)$ using a clean capillary tube.

Different types of mobile phases were investigated under the technique of try and error concept (T/E). Since the ethanol as an extracting solvent gives a polar nature of the crude extract so, multiple running systems related to polar systems were selected such as butanol - acetic acid - water 3:1:1 (BAW), as well as those related to slightly nonpolar ones such as chloroform - ethanol 9:1 (CE) and chloroform - acetone - butanol 85:15:20 (CAB).

Development chamber containing developing solvent ( BAW) was prepared, then a TLC plate was placed inside the closed chamber. When the solvent phase reached the top, the plate was air dried and visualization process was accomplished by both naked eye and long UV $(365 \mathrm{~nm})$. By the same way, both of $\mathrm{CE}$ and $\mathrm{CAB}$ solvent system were settled in development chamber individually.

Assessment of antifungal activity for partially purified fractions

All detected bands on TLC plate were screened for antifungal activity against all investigated fungi by the same way described for screening of antifungal activity of the crude extract.

This experiment was designated to determine the most potent fraction as well as comparing the results with those of the original crude extract.

Chromatographic characterization of the partially purified fraction with antifungal activity

Total soluble protein concentration

Total soluble proteins were estimated in both crude extract and fraction $-\mathrm{C}$, by the method of Lowry et al. (1951) using bovine serum albumin as a standard protein; the color was read at 750nm using spectrophotometer Speko II. The concentration of protein was calculated from the standard curve.

\section{Total soluble carbohydrates}

The total soluble carbohydrate content was estimated by the method of Hedge \& Hofreiter (1962). $0.2-1 \mathrm{ml}$ of working standard solution of five different test tube was taken then $4 \mathrm{ml}$ of anthrone reagent was added and the contents were mixed. The covered test tubes were put in water bath for $10 \mathrm{~min}$ then cooling to room temperature. Blank was prepared with $1 \mathrm{ml}$ of distilled water and $4 \mathrm{ml}$ of anthrone reagent. The optical density was measured in a photoelectric colorimeter at $620 \mathrm{~nm}$. Compute the concentration of the carbohydrates in the sample from the calibration curve.

\section{Mass spectroscopy (MS)}

Mass spectrum was carried out on Direct Probe Controller Inlet part to Single Quadropole mass analyzer (Thermo Scientific; GC/MS model ISQ LT) using Thermo X-Calibur software at the 
Regional Center for Mycology and Biotechnology (RCMB), Al-Azhar University, Nasr City, Cairo. The Mass spectroscopy system was used to confirm the purity of the compounds as well as to explore the characteristics of the isolated fraction and the expected molecular weight.

\section{Statistical analysis}

Statistical analysis of the obtained data was carried using one-way analysis of variance (ANOVA) according to Sendecor \& Cochran (1980)

\section{$\underline{\text { Results }}$}

Preliminary identification of fungal pathogens

A total of 15 fungal isolates related to four genera were recovered. The isolates identification was depending on microscopic and macroscopic examination according to Domsch et al. (1980). Only 4 fungal species were isolated; namely Geotrichum candidum (40\%), Alternaria alternata (33.3\%), Fusarium oxysporum (20\%) and Mucor hiemalis (6.7\%) (Fig. 1).

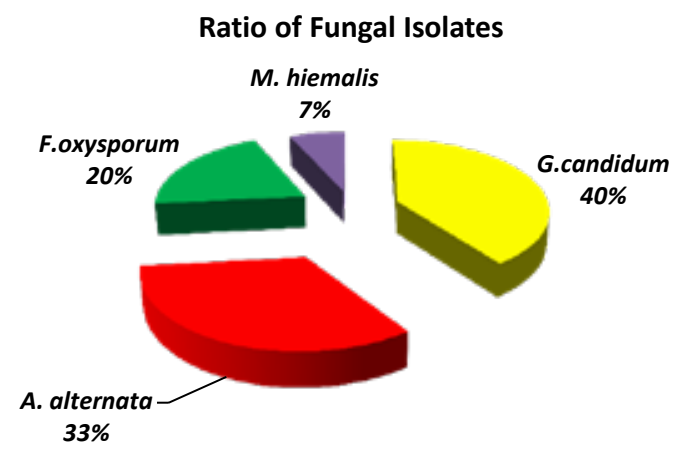

Fig. 1. Percentage of fungal isolates.

Evaluation of antifungal activity of ethanolic extracts of $S$. aromaticum

$S$. aromaticum extract recorded high values of inhibition zone diameter in corresponding to positive control (Table 1).
Effect of $S$. aromaticum in radial growth of the investigated fungi (test fungi)

Different concentrations of ethanolic extract of $S$. aromaticum; $1 \%, 2.5 \%, 5 \%, 12.5 \%, 25 \%$ and $50 \%$ were used for revealing the inhibitory effect of different concentrations of plant extract against each fungal species. Table 2 displays the effect of different concentrations of ethanolic $S$. aromaticum extract against test fungi which were affected by different degrees.

\section{Phytochemical screening of $S$. aromaticum}

The analysis of the preliminary phytochemical tests of the plant powder showed the presence of chemical constituents such like alkaloids, flavonoids, tannins, saponins, protein and carbohydrates; results were quantified to detect the concentrations of each constituent.

Clove extract appeared to be rich in phenolic acids as well as flavonoids in addition to alkaloids, tannins and saponins. Also, its content of proteins and nitrogenous compounds was much higher than the content of carbohydrates and oil (Table 3 ).

Chromatographic characterization of the crude extract of $S$. aromaticum

Chromatographic analysis of ethanolic crude extract by $G C / M S$

Chemical profile for ethanolic crude extract of clove indicated that it contains 18 different chemical compounds (Table 4 and Fig. 2). Four of these compounds (ethanol, 1,2-propanediol, dimethyl sulfoxide and dimethyl sulfone) belonged to the used solvents and their derivatives, other compounds such as hexadecenoic and octadecanoic esters were considered as precursors for other structural components such as fatty acids and lipid components. On the other hand, there were some compounds such as eugenol, trans-caryophyllene, humulene, anthracenedione, cedran-diol, citroflex A and lucenin 2 were detected.

TABLE 1. Antifungal activity of crude ethanolic plant extracts against the tested fungi measured as diameter of inhibition zone in $(\mathrm{mm})$.

\begin{tabular}{lcccc}
\hline Fungal species & A. alternate & F. oxysporum & G. candidum & M. hiemalis \\
\hline Diameter of positive control (mm) & $40.33 \pm 1.98$ & $40.33 \pm 1.98$ & $39.10 \pm 1.50$ & $41.56 \pm 1.50$ \\
Diameter of extract inhibition zone (mm) & $68.33 \pm 1.50$ & $44.66 \pm 1.50$ & $51.66 \pm 1.50$ & $61.66 \pm 1.98$ \\
\hline Data given are mean of triplicates \pm standard error (SE).
\end{tabular}


TABLE 2. Effect of different concentrations of ethanolic $S$. aromaticum extract against test fungi expressed as diameters of inhibition zone in $(\mathrm{mm})$.

\begin{tabular}{lcccc}
\hline $\begin{array}{l}\text { Concentration of } \\
\text { ethanolic extract }(\%)\end{array}$ & \multicolumn{5}{c}{ Diameters of inhibition zone in mm. } \\
\hline & A. alternata & F. oxysporum & G. candidum & M. heimalis \\
\hline 1 & - & - & - & - \\
2.5 & $11.66 \pm 2.20$ & - & $12.00 \pm 1.50$ & $11.33 \pm 1.50$ \\
5 & $13.00 \pm 1.90$ & - & $18.66 \pm 2.22$ & $18.00 \pm 1.10$ \\
12.5 & $37.33 \pm 1.50$ & $20.00 \pm 2.88$ & $24.00 \pm 1.50$ & $33.66 \pm 1.10$ \\
25 & $44.33 \pm 1.50$ & $34.00 \pm 1.98$ & $40.33 \pm 1.98$ & $45.00 \pm 1.98$ \\
50 & $55.00 \pm 1.20$ & $36.66 \pm 1.11$ & $43.00 \pm 1.10$ & $46.66 \pm 1.22$ \\
\hline
\end{tabular}

TABLE 3. Quantitative assessment of constituents in extracted materials of $S$. aromaticum.

\begin{tabular}{lc}
\hline Constituents & Conc.\% \\
\hline Total phenolic acid & 20.80 \\
Total flavonoids & 26.81 \\
Total carbohydrate & 2.23 \\
Total protein & 17.83 \\
Total alkaloids & 1.60 \\
Total tannins & 4.90 \\
Total saponins & 2.60 \\
Total oil & 0.90 \\
\hline
\end{tabular}

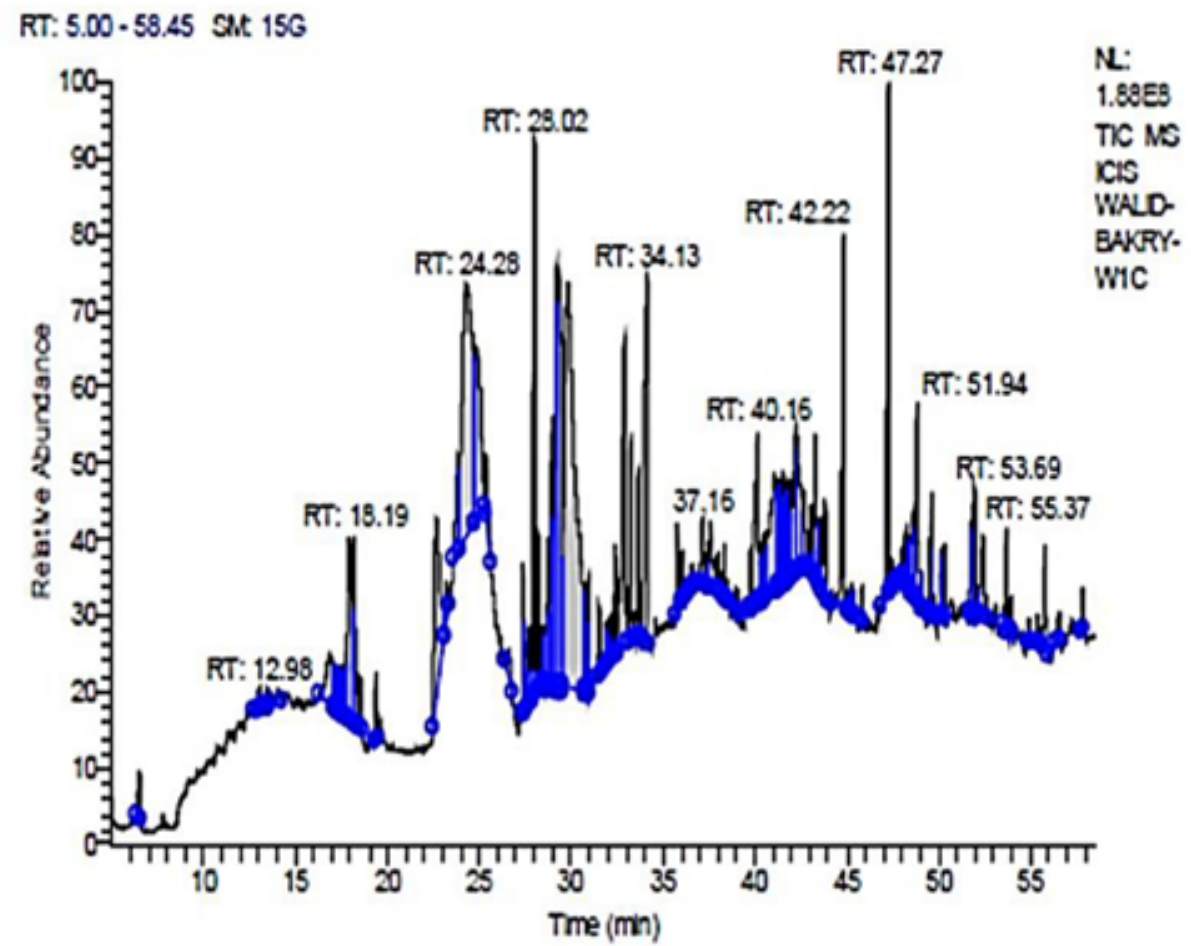

Fig. 2. GC/MS chromatogram of ethanolic crude extract of clove. 
TABLE 4. Chemical profile of ethanolic crude extract of $S$. aromaticum revealed by GC/MS

\begin{tabular}{|c|c|c|c|c|c|}
\hline No & $\begin{array}{c}\text { RT } \\
(\mathrm{min})\end{array}$ & Compound name & Area \% & Molecular formula & M. weight \\
\hline 1 & 6.53 & Ethanol & 0.28 & $\mathrm{C}_{2} \mathrm{H}_{6} \mathrm{O}$ & 46 \\
\hline 2 & 13.52 & 1,2-Propanediol & 0.77 & $\mathrm{C}_{3} \mathrm{H}_{8} \mathrm{O}_{2}$ & 76 \\
\hline 3 & 17.95 & Dimethyl Sulfoxide & 6.39 & $\mathrm{C}_{2} \mathrm{H}_{6} \mathrm{OS}$ & 78 \\
\hline 4 & 18.53 & Dimethyl sulfone & 0.29 & $\mathrm{C}_{2} \mathrm{H}_{6} \mathrm{O}_{2} \mathrm{~S}$ & 94 \\
\hline 5 & 19.39 & 3-Nonenoic acid, methyl ester & 0.34 & $\mathrm{C}_{10} \mathrm{H}_{18} \mathrm{O}_{2}$ & 170 \\
\hline 6 & 24.28 & Eugenol & 17.27 & $\mathrm{C}_{10} \mathrm{H}_{12} \mathrm{O}_{2}$ & 164 \\
\hline 7 & 27.44 & Nothosmyrnol & 0.65 & $\mathrm{C}_{11} \mathrm{H}_{14} \mathrm{O}_{2}$ & 187 \\
\hline 8 & 27.75 & trans-Caryophyllene & 0.50 & $\mathrm{C}_{15} \mathrm{H}_{24}$ & 204 \\
\hline 9 & 28.02 & Humulene & 3.33 & $\mathrm{C}_{15} \mathrm{H}_{24}$ & 204 \\
\hline 10 & 29.82 & Phenol,2-methoxy-4-(2 propenyl) -acetate & 25.39 & $\mathrm{C}_{12} \mathrm{H}_{14} \mathrm{O}_{3}$ & 206 \\
\hline 11 & 31.52 & Cedran-diol & 0.61 & $\mathrm{C}_{15} \mathrm{H}_{26} \mathrm{O}_{2}$ & 238 \\
\hline 12 & 34.13 & $\begin{array}{l}\text { 11,13-Dihydroxy-tetradec-5-ynoic acid, } \\
\text { methyl ester }\end{array}$ & 10.70 & $\mathrm{C}_{15} \mathrm{H}_{26} \mathrm{O}_{4}$ & 270 \\
\hline 13 & 36.07 & Octadecanoic acid,17-hydroxy-, methyl ester & 0.47 & $\mathrm{C}_{19} \mathrm{H}_{38} \mathrm{O}_{3}$ & 314 \\
\hline 14 & 41.07 & $\begin{array}{c}\text { Hexadecanoic acid,2,3-dihydroxypropyl } \\
\text { ester }\end{array}$ & 7.17 & $\mathrm{C}_{19} \mathrm{H}_{38} \mathrm{O}_{4}$ & 330 \\
\hline 15 & 41.85 & $\begin{array}{l}\text { 10-Hydroxy-5,7-dimethoxy-2,3-dimethyl- } \\
\text { 1,4-anthracenedione }\end{array}$ & 3.35 & $\mathrm{C}_{18} \mathrm{H}_{16} \mathrm{O}_{5}$ & 312 \\
\hline 16 & 44.83 & Citroflex A & 5.45 & $\mathrm{C}_{20} \mathrm{H}_{34} \mathrm{O}_{8}$ & 402 \\
\hline 17 & 47.24 & Oleic acid, eicosyl ester & 3.55 & $\mathrm{C}_{38} \mathrm{H}_{74} \mathrm{O}_{2}$ & 562 \\
\hline 18 & 48.81 & Lucenin 2 & 8.25 & $\mathrm{C}_{27} \mathrm{H}_{30} \mathrm{O}_{16}$ & 610 \\
\hline
\end{tabular}


Thin layer chromatography (TLC)

Chromatographic separation by BAW completely failed with no evidence demonstrating the migration of loaded sample from application position, thus, BAW was neglected and subsequently the pure polar nature of mobile phase in BAW was modified to another slightly nonpolar mobile phase which was $\mathrm{CE}$. Chromatographic separation by $\mathrm{CE}$ did not succeed completely because only one band was detected showing the ability of solvent system to upload the specimen but it was not able to fractionate this mixture to its subcomponents, hence, CE was also ignored and subsequently, $\mathrm{CAB}$ as running system was used.

$\mathrm{CAB}$ as a mobile phase was proposed to separate three bands (A, B and C) with Rf values $0.52,0.76$ and 0.87 ascendingly.

\section{Assessment of antifungal activity for partially purified fractions}

Three fractions were investigated by agar well diffusion technique of which only one induced antifungal activity. This fraction showed $\mathrm{Rf}$ value 0.87 . This compound exerted inhibitory effect against $G$. candidum, A. alternata and $M$. heimalis with diameter of inhibition zone 18.7 , 11.4 and $9.8 \mathrm{~mm}$, respectively. Whereas, it hadn't any fungal activity against $F$. oxysporum.

It should be noted that the values of inhibition zone belong to the purified fraction were much little than those belong to the original crude extract.
Total soluble protein concentration and carbohydrate contents in both crude extract and fraction - $C$

Total soluble proteins were estimated in both crude extract and fraction $-\mathrm{C}$; the measurements clarified that the total protein concentration in the crude extract is $85 \mathrm{mg} \mathrm{ml}^{-1}$ which was extremely reduced to $35 \mathrm{mg} \mathrm{ml}^{-1}$ in case of fraction $-\mathrm{C}$.

Total soluble carbohydrates were estimated in both crude extract and fraction $-\mathrm{C}$, the measurements clarified that the total soluble carbohydrates content in the crude extract is $505 \mathrm{mg} \mathrm{g}^{-1}$ in corresponding to $162.5 \mathrm{mg} \mathrm{g}^{-1}$ with extreme loss of carbohydrates content. Eventually, it could be deduced that the compound in charge had a core of chemical structure linked actually with a portion of glycoprotein, the core of this compound would be predicted by GC/MS.

\section{Mass spectrum characterization of the partially purified fraction}

GC/MS equipment was used to present the mass spectrum for fraction $-\mathrm{C}$ to test the purity and predict the structure of the compounds. GC/ MS exhibited the presence of only one peak (Fig. 3 ) as an indication for high purity of the fraction. Thus, it was easy to identify the compound via the prediction introduced by the searching library connected to GC/MS. The compound quietly may be glucoside $\beta$-sitosterol (Figs. 4 and 5).

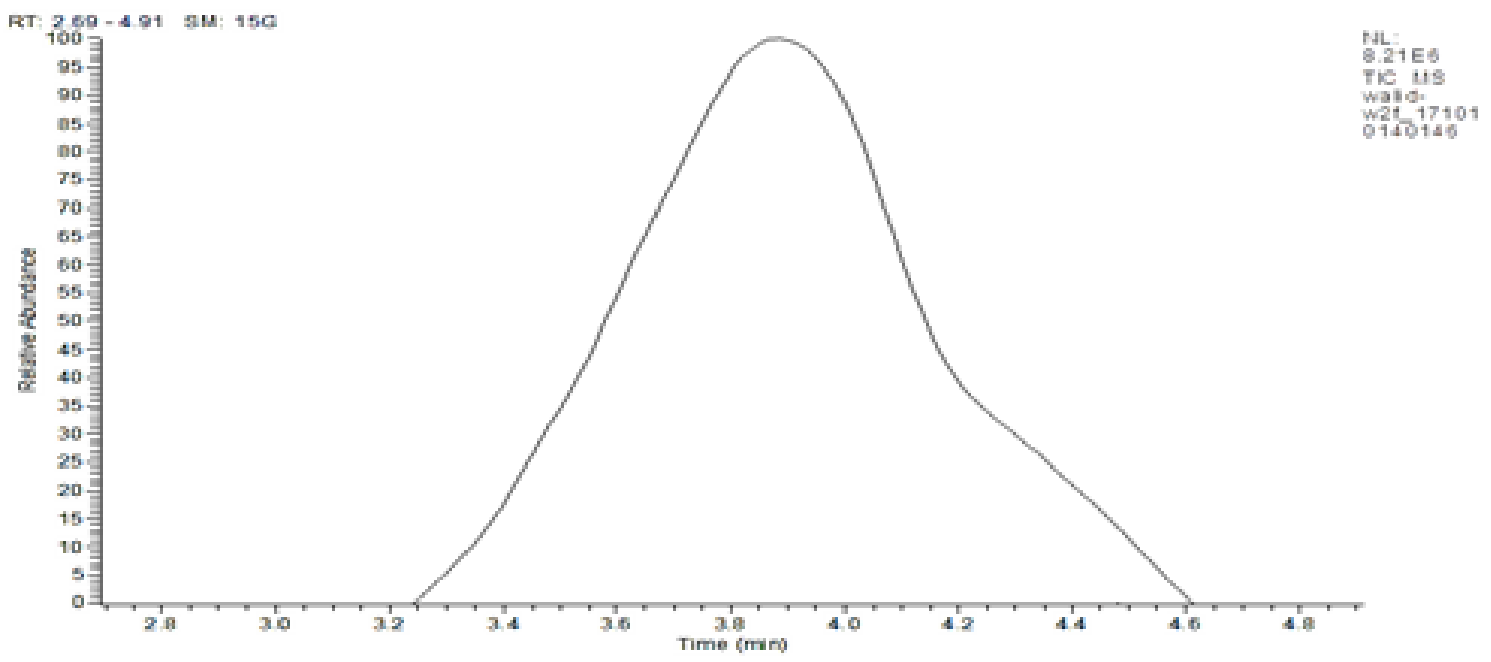

Fig. 3. GC/MS exhibited the presence of only one peak of the partially purified fraction -C. 


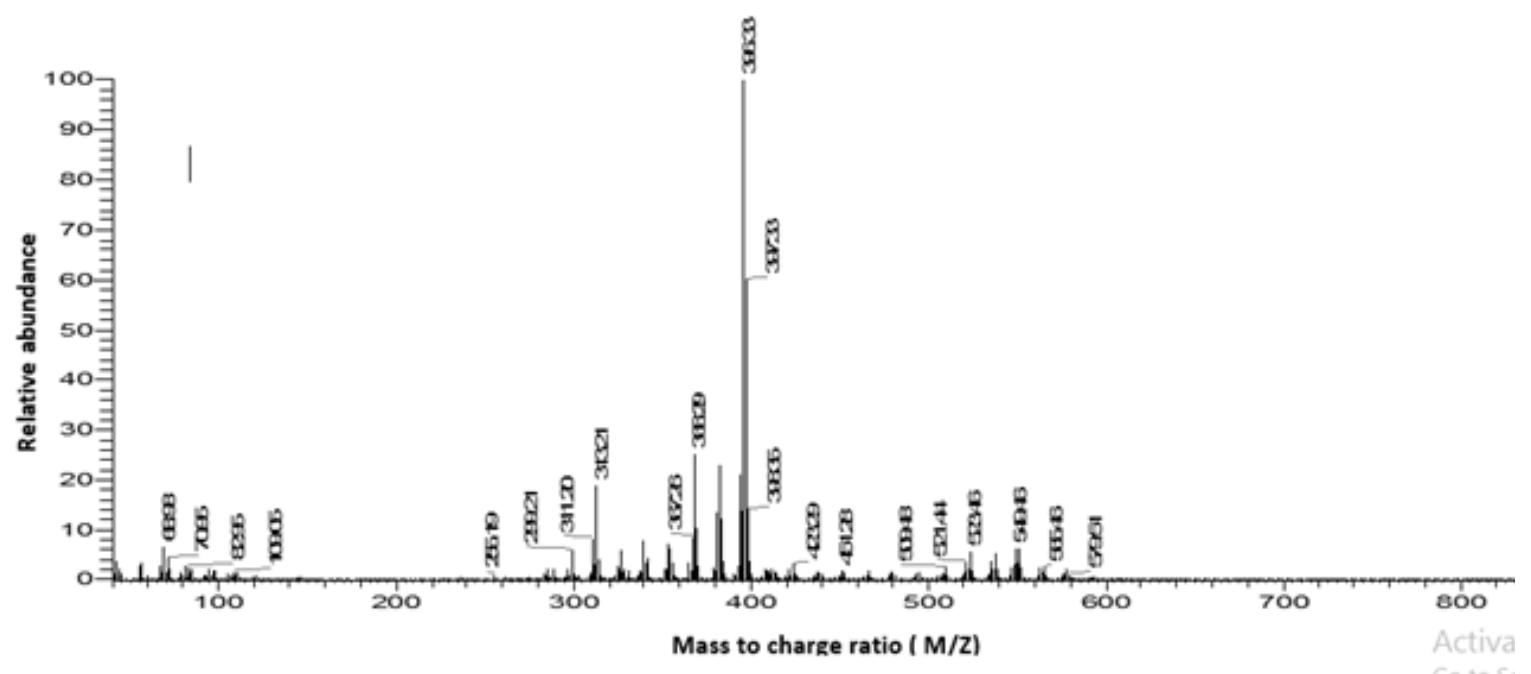

Fig. 4. Mass spectrum of fraction $-\mathrm{C}$.

Formula C35H6006, MW 576, CAS\# NA, Entry\# 640002

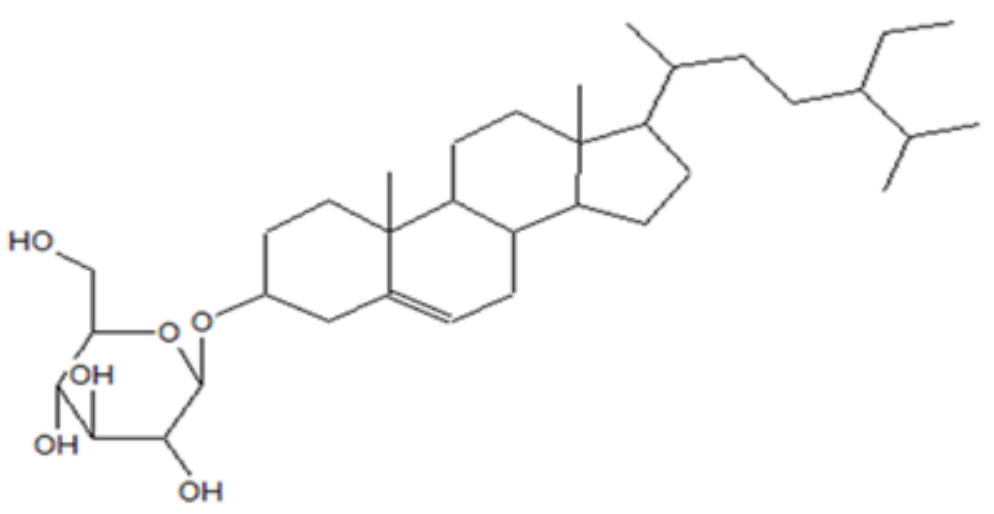

Fig. 5. The chemical structure of identified compound" Glucoside $\beta$-sitosterol".

Furthermore, The spectrum of component was compared with the spectrum of the component stored in the NIST library version (NIST Chemistry Web Book) (Joulain \& König, 1998) and a database of chemical molecules https:// pubchem.ncbi.nlm.nih.gov/search/search.cgi

\section{Discussion}

The results of this study showed that the ethanolic extract of S. aromaticum L. showed strong antifungal effect against all tested fungi. Different concentration of Syzygium aromaticum extract showed variation among fungal species. The smallest inhibition zone was observed at concentration of $2.5 \%$ against A. alternata, $G$. candidum and $M$. heimalis; with diameter of $11.66,12.0$ and $11.33 \mathrm{~mm}$, respectively. While F. oxysporum gives minimum inhibition zone of $20.0 \mathrm{~mm}$ in diameter at relatively higher concentration (12.5\%).

These results agree with the results recorded by Bander (2011) who reported that the alcoholic extract of $S$. aromaticum plant and its essential oil exhibited strong effect against all tested Trichophyton species.

Antifungal activity exhibited by S. aromaticum may attribute to the presence of secondary metabolites. These compounds can interfere with pathogens by different mode of action. Freiesleben \& Jäger (2014) had previously investigated the correlation between the biosynthetic group of secondary metabolites in plants and their antifungal mechanisms of action. From looking at the composition of the fungal cell, at least 6 different antifungal mechanisms can be suggested. 
These mechanisms include inhibition of cell wall formation, cell membrane disruption, dysfunction of the fungal mitochondria, inhibition of cell division, inhibition of RNA/DNA synthesis or protein synthesis and inhibition of efflux pumps.

Different types of secondary metabolites such as alkaloids, steroids, tannins, and phenol compounds, flavonoids, resins, fatty acids, gums have been identified as antifungal and antibacterial agent in plants (Dorman \& Deans, 2000; Wallace, 2004; Han \& Paik, 2010; Gokhale \& Wadhwani, 2015 and Ryu et al., 2016).

In the present investigation, the chemical nature of active components in $S$. aromaticum was identified by qualitative and quantitative preliminary phytochemical tests, it appeared to be rich in phenolic acids, flavonoids, alkaloids, sterol, tannins and saponins. In addition to proteins, nitrogen, carbohydrates and oil. The phytochemical results obtained in this study agree with Tanko et al. (2008) who concluded the presence of flavonoids, resins, glycosides, tannins, saponins and alkaloids in the ethanolic extract of $S$. aromaticum. In another study done by Upadhyaya et al. (2018), phytochemical screening was carried out on ethanol, chloroform and distilled water extracts of clove for its chemical composition. Qualitative phytochemical analysis of these extracts confirms the presence of alkaloids, terpenoids, flavonoids, saponins, steroids and tannins.

Investigation chemical nature of active antifungal component in $S$. aromaticum was carried out by using GC/MS to predict the chemical profile of the crude ethanolic extract of clove. The results revealed that the crude extract contained 18 different chemical compounds with different concentrations such like eugenol, trans-caryophyllene, humulene, anthracenedione, cedran-diol, citroflex A and lucenin 2. This result is consistent with that of Wagn et al. (2017) who found that the major compounds in clove alcoholic extract analysis by GC/MS were eugenol, acetyl eugenol, caryophyllene, and humulene followed by a-farnesene and caryophylleneoxide. These notable differences in composition may be due to extraction methods as well as genetic diversity and agronomic treatments (Mahanta et al., 2007).

Separation the components of the crude extract and purification the effective compound in charge using TLC technique revealed that only one fraction with $\mathrm{Rf}$ value 0.87 showed antifungal activity against all tested fungi except $F$. oxysporum. It was also observed that the values of inhibition zone belong to the purified fraction were too much little than those belong to the original crude extract and this may be due to the nature of the compound in charge which might have either a portion of protein or a portion of carbohydrate via glucosidal bond. This hypothesis is consistent with Khan \& Nasreen (2010), in the fact that the antifungal activity exhibited by plants might be attributed to the presence of either single or synergetic effect of more than one compound. Synergism is observed when the effect of the combined substances is greater than the sum of the individual effects (Burt, 2004). It has been also demonstrated that the synergistic effect of some secondary metabolites is probable due to the interaction of these components with different proteins or enzymes (Bassolé \& Juliani, 2012). So that the purified fraction was estimated for detection of proteins as well as carbohydrates and also would be compared with the content on proteins and carbohydrates in the crude extract.

Protein and carbohydrate contents in the crude extract were reduced in case of purified fraction (C). It was previously suggested that carbohydrates influence on production of secondary metabolites (Sørensen \& Giese, 2013). Eventually, it could be deduced that the compound in charge had a core of chemical structure linked actually with a portion of glycoprotein, the core of this compound would be predicted by GC/MS. Mass spectrum characterization of the partially purified fraction showed only one peak as an evidence for high purity of the fraction. It was clear that the compound may be glucoside $\beta$-sitosterol which approved the expectation of glucosidal bond especially when the results of total carbohydrates were taken in consideration.

Glucoside $\beta$-sitosterol was previously isolated from different plant species and exhibited antimicrobial activity. It was isolated from ethanolic extract of the root heart wood of Acacia senegal, as white granules (Jain et al., 2012). Further researches have indicated that such phytosterol compounds serve to stabilize phospholipid bilayers in plant cell membranes and display antifungal properties against human and plant origin (Moreau et al., 2002; Khan et al., 2007; Kuigoua, 2010, Singh et al., 2011 and Arora \& Kalia, 2013). 
Moreover, other studies emphasized the isolation of $\beta$-sitosterol, $\beta$-sitosterol 3-O- $\beta$ D-glucopyranoside and other five compounds namely oleanolic acid lactone, nigricin, flavaellagic acid, $2 \alpha$ - hydroxyoleanolic acid, 3ß-hydroxy-11-oxo-olean-12-en-28-oic acid from S. aromaticum (Begum et al., 2014).

The focus should be shifted to exploit $S$. aromaticum as a suitable, ecofriendly and safe alternative for chemical pesticides and its potential use as biological fungicide for the control of postharvest infections which affecting two of the most important economic plants in Egypt.

\section{References}

Abdullah, Q., Mahmoud, A. and Al-Harethi, A. (2016) Isolation and identification of fungal post-harvest rot of some fruits in Yemen. PSM Microbiology, 1(1), 36-44.

Al-Kuraishi, R.S., Al-Shamma, L.M. and Al-Mathkhury, H.J. (2013) Effect of seed oil Ricinus communis on $E$. coli isolated from recurrent urinary tract infections. Iraqi Journal of Science, 54(4), 851-855.

Arora, M. and Kalia, A. (2013) Isolation and characterization of stigmasterol and $\beta$-sitosterold-glycoside from ethanolic extract of the stems of Salvadora persica L. International Journal of Pharmacy and Pharmaceutical Sciences, 5(1), 245249.

Balbaa, S., Hilal, S. and Zaki, A. (1981) "Medicinal Plant Constituents". General Organization for University and School Books $3^{\text {rd }}$ ed. pp.190-255.

Bander, K.I. (2011) Anti-Fungal activity of some plant extract against some Trichophyton species. Tikrit Medical Journal, 17(1), 81-87.

Bassolé, I. and Juliani, H. (2012) Essential oils in combination and their antimicrobial properties', Molecule, 4(17), 3989-4006.

Beever, R. and Bollard, E. (1970) The nature of the stimulation of fungal growth by potato extract. Microbiology, 60(2), 273-279.

Begum, S., Siddiqui, B.S., Khatoon, R. and Aftab, F. (2014) Phytochemical studies on Syzygium aromaticum linn. J. Chem. Soc. Pak. 36, 512.
Bhowmik, D., Kumar, K.S., Yadav, A., Srivastava, S., Paswan, S. and Dutta, A.S. (2012) Recent trends in Indian traditional herbs Syzygium aromaticum and its health benefits. Journal of Pharmacognosy and Phytochemistry, 1(1), 13-23.

Bhuyan, D. and Das, J. (2012) Plant extracts as biofungicides: A review. Electronic Journal of Environmental Sciences, 5, 49-54.

Burt, S. (2004) Essential oils: Their antimicrobial properties and potential applications in foods: A review. Int. J. Food Microbiol. 94, 223-253.

Chaieb, K., Zmantar, T., Ksouri, R., Hajlaoui, H., Mahdouani, K., Abdelly, C. and Bakhrouf, A. (2007) Antioxidant properties of essential oil of Eugenia cryophyllata and its antifungal activity against a large number of clinical Candida species. Mycosis, 50(5), 403-406.

Chang, C.C., Yang, M.H., Wen, H.M. and Chern, J.C. (2002) Estimation of total flavonoid content in propolis by two complementary colorimetric methods. Journal of Food and Drug Analysis, 10(3), 178-182.

Chaplin, M.F. and Kennedy, J.F. (1994) "Carbohydrate Analysis: A Practical Approach", $2^{\text {nd }}$ ed. School of Applied Science, South Bank University, London (United Kingdom). IRL Press Ltd.

Droby, S., Chalutz, E., Wilson, C. and Wisniewski, M. (1992) Biological control of postharvest diseases: A promising alternative to the use of synthetic fungicides. Phytoparasitica, 20(1), 149-153.

Domsch, K.H., Gams, W. and Anderson, T.H. (1980) Compendium of Soil Fungi", Vol 1. Academic Press (London) Ltd. UK.

Dorman, H.D. and Deans, S.G. (2000) Antimicrobial agents from plants: antibacterial activity of plant volatile oils. Journal of Applied Microbiology, 88(2), 308-316.

Elujoba, A.A., Odeleye, O. and Ogunyemi, C. (2006) Traditional medicine development for medical and dental primary health care delivery system in Africa. African J. Traditional. Complementary and Alternative Medicines, 2(1), 46-61.

Freiesleben, S. and Jäger, A. (2014) Correlation between plant secondary metabolites and their 
antifungal mechanisms: A review. Medicinal and Aromatic Plants, 3(2), 1-6.

Gams, W., Bissett, J. and Malik, A.F. (1998) Morphology and identification of Trichoderma. Trichoderma and Gliocladium, 1, 3-34.

Gokhale, M. and Wadhwani, M. (2015) Antimicrobial activity of secondary metabolites from plants: A review. International Journal of Pharmacognosy, 2, 60-65.

Hamini-Kada, N., Hamdane, F., Boutoutaou, R., Kihal, M. and Henni, J. (2014) Antifungal activity of clove (Syzygium aromaticum L.) essential oil against phytopathogenic fungi of tomato (Solanum lycopersicum L.) in Algeria. Journal of Experimental Biology and Agricultural Sciences, 2(5), 447-454.

Han, A.R. and Paik, Y.S. (2010) Identification and PEP inhibitory activity of acetophenone glucosides from the clove buds (Syzygium aromaticum). Journal of the Korean Society for Applied Biological Chemistry, 53(6), 847-851.

Harborne, A. (1998) Phytochemical methods: A guide to modern techniques of plant analysis. Brittonia, 42(2), 115-140.

Harris, C.A., Renfrew, M.J. and Woolridge, M.W. (2001) Assessing the risks of pesticide residues to consumers: Recent and future developments. Food Additives \& Contaminants, 18(12), 1124-1129.

Hedge, J. and Hofreiter, B. (1962) Determination of reducing sugars and carbohydrates: Anthrone colorimetric method. Methods in Carbohydrate Chemistry, 1, 389-390.

Jain, R., Sharma, P., Bhagchandani, T. and Jain, S.C. (2012) Phytochemical investigation and antimicrobial activity of Acacia senegal root heartwood. Journal of Pharmacy Research, 5, 4934-4938.

James, C.S. (1995) "Analytical Chemistry of Foods", $1^{\text {st }}$ ed., Chapman and Hall, New York, ISBN: 978-14613-5905-0, 178p.

Joulain, D. and König, W.A. (1998) "The Atlas of Spectral Data of Sesquiterpene Hydrocarbons", EB-Verlag.
Khan, Z. and Nasreen, S. (2010) Phytochemical analysis, antifungal activity and mode of action of methanol extracts from plants against pathogens. Journal of Agricultural Technology, 4(6), 793-805.

Khan, A., Haque, E., Rahman, M.M., Mosaddik, A., Rahman, M. and Sultana, N. (2007) A new triterpenoid from roots of Laportea crenulata and its antifungal activity. Natural Product Research, 21(11), 959-966

Kim, H.M., Lee, E.H., Hong, S.H., Song, H.J., Shin, M.K., Kim, S.H. and Shin, T.Y. (1998) Effect of Syzygium aromaticum extract on immediate hypersensitivity in rat. J. Ethnopharmacology, 60(2), 125-131.

Kuigoua, G. (2010) Minor secondary metabolic products from the stem bark of Plumeria rubra Linn. displaying antimicrobial activities. Planta Medica. 76(6), 620-625.

Kumar, Y., Agarwal, S., Srivastava, A., Kumar, S., Agarwal, G. and Khan, M.Z.A. (2014) Antibacterial activity of clove (Syzygium aromaticum) and garlic (Allium sativum) on different pathogenic bacteria. International Journal of Pure and Applied Bioscience, 2(3), 305-311.

Lowry, O.H., Rosebrough, N.J., Farr, A.L. and Randall, R.J. (1951) Protein measurement with the Folin phenol reagent. Journal of Biological Chemistry, 193(1), 265-275.

Mahanta, J., Chutia, M., Bordoloi, M., Pathak, M., Adhikary, R. and Sarma, T. (2007) Cymbopogon citratus $\mathrm{L}$. essential oil as a potential antifungal agent against key weed moulds of Pleurotus spp. spawns. Flavour and Fragrance Journal, 22(6), 525-530.

Maurya, S. and Singh, D. (2010) Quantitative analysis of total phenolic content in Adhatoda vasica Nees extracts. International Journal of Pharm Tech. Research, 2(4), 2403-2406.

Miyazawa, M. and Hisama, M. (2003) Antimutagenic activity of phenylpropanoides from clove $(S$. aromaticum). Journal of Agriculture and Food Chemistry, 51(22), 6413-6422.

Moreau, R.A., Whitaker, B.D. and Hicks, K.B. (2002) Phytosterols, phytostanols, and their conjugates in foods: Structural diversity, quantitative analysis and 
health-promoting uses. Progress in Lipid Research. Pergamon, 41(6), 457-500.

Okwu, D. and Ukanwa, N. (2007) Nutritive value and phytochemical contents of fluted pumpkin (Telfaria occidentalis Hook F) vegetable grown with different levels of turkey droppings. $8^{\text {th }}$ African Crop Science Society Conference, El-Minia, Egypt, 27-31 October 2007, African Crop Science Society, pp. 1759-1764.

Polshettiwar, S., Ganjiwale, R., Wadher, S. and Yeole, P. (2007) Spectrophotometric estimation of total tannins in some ayurvedic eye drops. Indian Journal of Pharmaceutical Sciences, 69(4), 574.

Rojas, J.J., Ochoa, V.J., Ocampo, S.A. and Muñoz, J.F. (2006) Screening for antimicrobial activity of ten medicinal plants used in Colombian folkloric medicine: A possible alternative in the treatment of non-nosocomial infections. BMC Complementary and Alternative Medicine, 6(1), 2.

Ryu, B., Kim, H.M., Woo, J.H., Choi, J.H. and Jang, D.S. (2016) A new acetophenone glycoside from the flower buds of Syzygium aromaticum (cloves). Fitoterapia, 115, 46-51.

Singh, O., Ali, M. and Akhtar, N. (2011) New antifungal xanthones from the seeds of Rhus coriaria L. Zeitschrift für Naturforschung C, 66(1-2), 17-23.

Sendecor, G.W. and Cochran, W.G. (1980) "Statistical Methods", $6^{\text {th }}$ ed. Iowa State University Press.

Sørensen, J.L. and Giese, H. (2013) Influence of carbohydrates on secondary metabolism in Fusarium avenaceum. Toxins, 5(9), 1655-63.

Srivastava, K. and Malhotra, N. (1991) Acetyl euginol, a component of oil of cloves (Syzygium aromaticum L.) inhibits aggregation and alters arachidonic acid metabolism in human blood platelets, Prostaglandins. Leukotrienes and Essential Fatty
Acids, 42(1), 73-81.

Sulieman, A.M.E., Boshra, I. and El Khalifa, E. (2007) Nutritive value of clove (Syzygium aromaticum) and detection of antimicrobial effect of its bud oil. Research Journal Microbiology, 2(3), 266-271.

Tanko, Y., Mohammed, A., Okasha, M., Umah, A. and Magaji, R. (2008) Anti-nociceptive and anti-inflammatory activities of ethanol extract of Syzygium aromaticum flower bud in wistar rats and mice. African Journal of Traditional, Complementary and Alternative Medicines, 5(2), 209-212.

Upadhyaya, S., Yadav, D., Chandra, R. and Arora, N. (2018) Evaluation of antibacterial and phytochemical properties of different spice extracts. African Journal of Microbiology Research, 12(2), 27-37.

Wagn, Y., Ding, Y., Wang, S., Chen, H., Zhang, H., Chen, W. and Chen, Y.Q. (2017) Extract of Syzygium aromaticum suppress eEF1A protein expression and fungal growth. Journal of Applied Microbiology, 123(1), 80-91.

Wallace, R.J. (2004) Antimicrobial properties of plant secondary metabolites. Proceedings of the Nutrition Society. Cambridge University Press. 63(4), pp. 621-629.

Woo, C. and Püls, M. (1977) The Peierls mechanism in MgO. Philosophical Magazine, 35(6), 1641-1652.

(Received 15/5/2018; accepted $11 / 10 / 2018$ ) 


\title{
في المختبر: تقييم تأثير المستخلص الكحولي للقرنفل كعامل مكافحة بيولوجية ضد أمراض

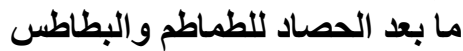

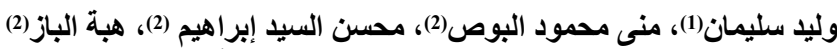

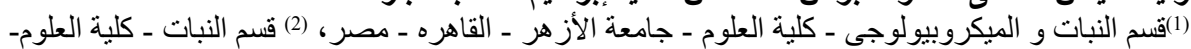 \\ جامعة بورسعيد - بورسعيد - مصر الميرو
}

\begin{abstract}
تقوم الدر اسة على عزل وتعريف الفطريات الممرضة لنباتى الطماطم و البطاطس فى مرحلة ما بعد الحصاد وهى Alternaria alternata ،Mucor hiemalis ،Geotrichum candidum ،Fusarium oxysporum لاختبار مدى تأثير الدستخلص الكحولى للبر اعم الجافة للقر نفل على هذه الفطريات. وأظهرت النتائج أن المستخلص

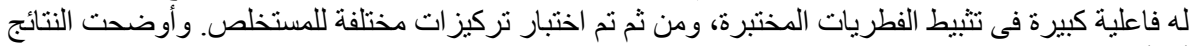

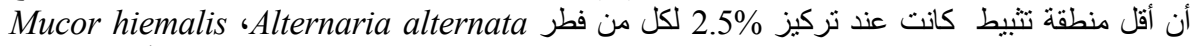

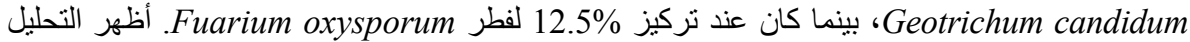

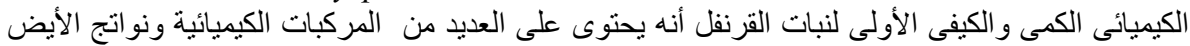

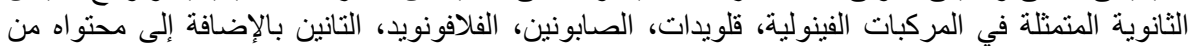

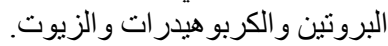

كما تم التعرف على مكونات المستخلص الأيثانولى للقرنفل بجهاز الكرموتوجر افى الغازى المزود بمطياف GC/MS

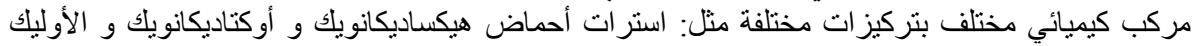

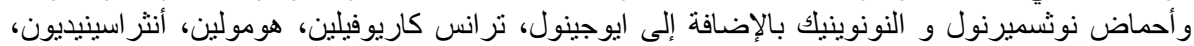
سيدران-ديول، سيتروفلكس أو لوسينين 2.

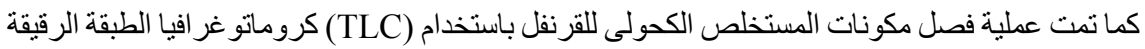

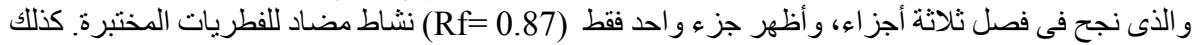

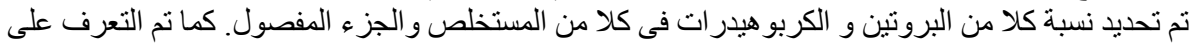

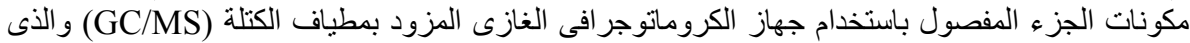
رجح أن المادة الفعالة هى glucoside $\beta$-sitosterol. 